\title{
Analisis Kandungan Asam Organik pada Beberapa Sampel Gula Aren
}

\author{
Kurniawan A. Saputraa*, Julius S. Pontoha, Lidya I. Momuata \\ aJurusan Kimia, FMIPA, Unsrat, Manado
}

KA T A K U N C I

Gula aren

Asam organik

HPLC

\section{K E YW O R D S}

Palm sugar

Organic acid

HPLC

\begin{tabular}{l}
$\overline{\text { AVAILABLE ONLINE }}$ \\
\hline 10 Februari 2015 \\
\hline
\end{tabular}

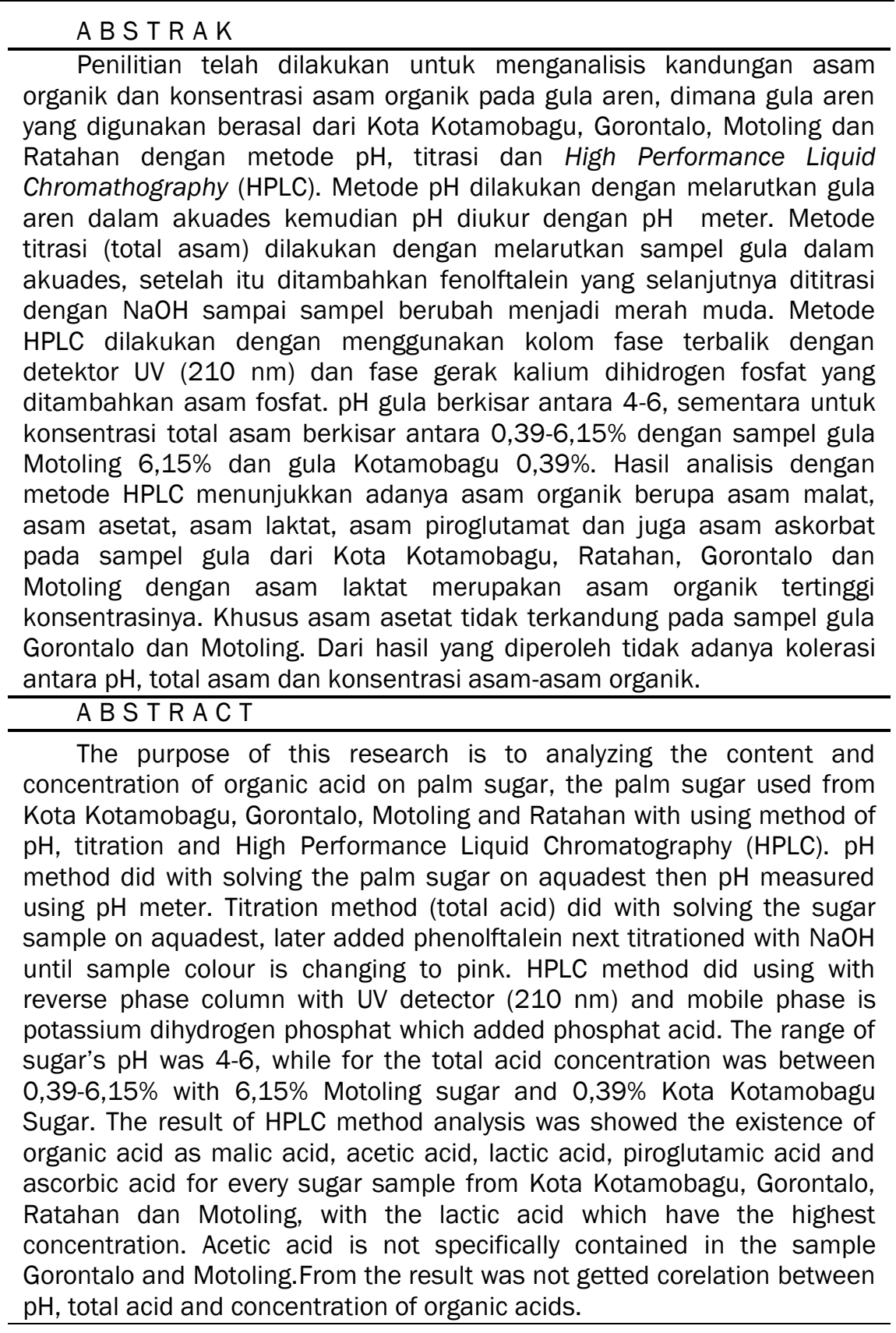




\section{Pendahuluan}

Indonesia merupakan Negara yang berada di wilayah tropis yang menjadikan Indonesia cocok sebagai tempat tumbuh berbagai macam tanaman. Salah satu tanaman yang dapat tumbuh subur di Indonesia adalah tanaman aren. Tanaman aren ini memiliki nilai ekonomis yang tinggi karena hampir seluruh bagian tanaman ini dapat dimanfaatkan untuk keperluan kehidupan. Salah satunya yaitu dapat menghasilkan nira, yang selanjutnya nira ini dapat diolah menjadi gula merah.

Gula merupakan salah satu kebutuhan pokok manusia pada saat ini, karena gula mempunyai berbagai fungsi baik dalam industri makanan maupun industri bukan makanan seperti industri obat-obatan, bahan baku industri fermentasi dan sebagai sumber energi yang terbarukan (Pelealu et al., 2011).

Gula dapat berasal dari aren, tebu, kelapa dan juga siwalan. Akan tetapi masyarakat Indonesia terutama masyarakat pedesaan memilih gula aren untuk pembuatan jajanan tertentu dengan alasan bahwa gula tersebut mempunyai cita rasa dan aroma spesifik yang tidak dapat digantikan oleh gula putih atau pemanis lain (Sihombing, 1995).

Adanya asam-asam organik seperti asam malat, asam sitrat dan asam laktat, akan memberikan rasa yang khas, dikarenakan asam-asam organik diketahui mempunyai peran yang penting dalam cita rasa makanan (Suzanne, 2009).

Asam organik adalah komponen umum dalam makanan dan minuman, dan memainkan peran penting dalam karakteristik produk, seperti rasa dan aroma. Asam organik ditemukan di banyak produk makanan termasuk buah-buahan, keju, dan berbagai minuman seperti jus dan anggur (Suzanne, 2009).

Suzanne (2009) mengemukakan bahwa asamasam organik dapat dianalisis dengan menggunakan dua metode yaitu dengan mengukur keasaman $(\mathrm{pH})$ dan dengan metode titrasi. Analisis asam-asam organik pada makanan dapat juga dilakukan dengan menggunakan High Performance Liquid Chromathography (HPLC) (Nour et al., 2010). Oleh karena itu tujuan penelitian ini untuk mengetahui asam-asam organik yang terkandung dalam gula aren dan konsentrasi dari setiap asam organik itu.

\section{Metode}

\subsection{Bahan dan Alat}

Peralatan yang digunakan dalam penelitian ini adalah Alat-alat yang digunakan berupa alat-alat gelas secara umum phyrex, pipet, pH meter, aluminium foil, neraca elektrik, sendok, pengaduk magnetik, kertas saring whatman 0,2 dan 0,45 $\mu \mathrm{m}$, cawan, oven, desikator, penjepit cawan, neraca analitik dan alat
High Performance Liquid Chromatograph (HPLC) merek Shimadzhu LC 20 dengan kolom YMC Triart C18 detektor UV-VIS.

Sampel gula aren yang diperoleh dari pasar Lokal di Manado, asam-asam standar Merck berupa asam sitrat, asam laktat, asam piroglutamat, asam malat. Asam askorbat, asam fosfat $85 \%, \mathrm{NaOH}$, $\mathrm{KH}_{2} \mathrm{PO}_{4}$, bahan lainnya yaitu akuades.

\subsection{Preparasi Sampel dan Asam Standar}

Sampel gula aren (gula merah) yang sudah disiapkan dihaluskan sampai halus kemudian siapkan sampel 2,5 g yang kemudian dilarutkan dengan akuades dan untuk 5 g dilarutkan dengan fase gerak dalam $100 \mathrm{~mL}$ guna pengujian berikutnya.

Asam standar yang digunakan berada dalam bentuk larutan dan juga serbuk. Untuk asam dalam bentuk larutan seperti asam laktat dan asam asetat diambil sebanyak $10 \mathrm{~mL}$ kemudian ditambahkan 90 $\mathrm{mL}$ fase gerak sedangkan ; untuk asam dalam bentuk serbuk seperti asam fumarat, asam piroglutamat, asam malat dan sitrat, ditimbang sebanyak 0,1 g dan dilarutkan dengan fase gerak hingga menjadi $100 \mathrm{~mL}$. Setelah itu asam-asam standar tersebut di variasikan untuk kurva standar. Variasi dari setiap asam yang digunakan mulai dari konsentrasi 0,01\%, 0,02\%, $0,03 \%, 0,04 \%, 0,05 \%, 0,1 \%, 0,2 \%, 0,3 \%$ dan $0,4 \%$ (Limo et al., 2015).

\subsection{Analisa Asam Organik Pengukuran pH (BSES, 1991)}

Sampel sebanyak $5 \mathrm{~g}$ di larutkan dengan menggunakan akuades sebanyak $100 \mathrm{~mL}$. pH larutan sampel diukur dengan menggunakan $\mathrm{pH}$ meter yang telah dikalibrasi dengan menggunakan larutan buffer $\mathrm{pH} 4, \mathrm{pH} 7$ dan $\mathrm{pH}$ 10. Elektroda diangkat dari larutan sampel dan kemudian dicuci dengan air. Saat tidak digunakan elektroda harus diredam dengan air.

\section{Titrasi Sampel dengan $\mathrm{NaOH}$}

Sampel sebanyak 2,5 g dilarutkan dengan akuades hingga $100 \mathrm{~mL}$ dan ditambahkan indikator fenolftalein sebanyak 2-3 tetes. Kemudian larutan $\mathrm{NaOH}$ 0,1 M dimasukkan ke dalam buret dan diteteskan ke dalam sampel sampai terjadi perubahan warna inikator dari tidak berwarna menjadi merah muda.

Konsentrasi dihitung dengan menggunakan :

$$
\begin{aligned}
& \text { (\%) Asam }=\frac{M \times V 1 \times E q w t}{V 2 \times 1000} \times 100 \% \\
& \text { dengan : } \\
& M=\text { Molaritas titran }(\mathrm{mmol} / \mathrm{mL}) \\
& \mathrm{V}_{1}=\text { volume titran }(\mathrm{mL}) \\
& \mathrm{V}_{2}=\text { volume sampel }(\mathrm{mL})
\end{aligned}
$$

Eq. wt . = Berat Molekul Asam $(\mathrm{mg} / \mathrm{mmol})=$ Asam Laktat $(90,08 \mathrm{mg} / \mathrm{mmol})$ 


\section{Analisis dengan HPLC (Nour, et al., 2010).}

Asam organik pada sampel dipisahkan dengan menggunakan HPLC merek Shimadzu LC 20 A dengan kolom YMC Triart C-18. Fase gerak yang digunakan terdiri dari $50 \mathrm{mM}$ larutan fosfat yang dibuat dari 6,8 g kalium dihidrogen fosfat dalam $900 \mathrm{~mL}$ akuades, selanjutnya $\mathrm{pH}$ disesuaikan dengan menambahkan asam fosfat sampai $\mathrm{pH}=2,8$. Selanjutnya larutan ditambahkan kembali dengan akuades sampai 1000 $\mathrm{mL}$. Fase gerak disaring dengan menggunakan kertas saring 0,45 $\mu \mathrm{m}$. Setelah itu, alat HPLC diatur pada suhu ruang $25{ }^{\circ} \mathrm{C}$, dengan panjang gelombang 210 $\mathrm{nm}$. Laju alir fase gerak adalah $0,7 \mathrm{~mL} /$ menit. Kemudian alat HPLC dibiarkan sampai baseline stabil. Asam standar dan sampel sebanyak 5 g yang telah dilarutkan dengan fase gerak, diambil sebanyak 100 $\mu \mathrm{L}$ kemudian disaring menggunakan kertas saring 0,2 $\mu \mathrm{m}$ selanjutnya disuntikkan ke dalam HPLC.

\section{Hasil dan Pembahasan}

\subsection{Derajat Keasaman Gula Aren (pH)}

Derajat keasaman dari gula aren dapat mempengaruhi kualitas dari pada gula aren itu sendiri. Kualitas gula aren yang baik memiliki pH 6-7. Hasil penelitian derajat keasaman gula dari berbagai gula aren pada penelitian ini dapat dilihat pada Tabel 1.

Tabel 1 - Pengukuran pH dari masing-masing Gula Aren

\begin{tabular}{|c|c|}
\hline Jenis Sampel & $\mathrm{pH}$ \\
\hline Gula Kotamobagu & 5,88 \\
Gula Gorontalo & 5,42 \\
Gula Ratahan & 5,44 \\
Gula Motoling & 5,17 \\
\hline
\end{tabular}

Tabel 1 menunjukkan $\mathrm{pH}$ gula merah berkisar $5,17-5,88$. Di antara keempat sampel gula aren, gula Motoling memiliki keasaman yang paling tinggi. Sejauh ini persyaratan mengenai $\mathrm{pH}$ pada gula aren belum ditentukan oleh Standart Nasional Indonesia sehingga lewat penelitian ini bisa membantu pihak yang berwenang untuk menetapkan standar $\mathrm{pH}$ untuk produk pada gula aren.

\subsection{Titrasi sampel dengan $\mathrm{NaOH}$}

Data hasil pengujian titrasi dihitung konsentrasi dengan menggunakan salah satu asam standar yaitu asam laktat, karena menurut itoh et al., (1985) bahwa asam yang tertinggi pada nira adalah asam laktat. Perhitungan konsentrasi dapat dilihat pada Tabel 2.

Perhitungan konsentrasi asam menggunakan metode titrasi dengan menggunakan asam laktat sebagai standar tertera pada Tabel 5. Konsentrasi gula Kota Kotamobagu diperoleh 0,39\%, gula Gorontalo 0,42\%, gula Ratahan 0,50\% dan untuk Motoling 6,15\%. Dari hasil di atas dapat dilihat bahwa konsentrasi asam laktat yang terkandung dalam gula
Motoling lebih tinggi dari pada gula yang lainnya. Hal ini dikarenakan warna dari sampel gula Motoling saat ditambahkan dengan aquades berwarna kehitaman dibandingkan dengan warna sampel gula Kota Kotamobagu, begitu juga dengan sampel gula Gorontalo dan sampel gula Ratahan, sehingga membutuhkan $\mathrm{NaOH}$ yang lebih untuk merubah warna smpel menjadi merah muda.

Tabel 2 - Perhitungan Konsentrasi dengan metode Titrasi (g/100g)

\begin{tabular}{|c|c|}
\hline Jenis Sampel & $\mathrm{pH}$ \\
\hline Gula Kotamobagu & 0,39 \\
Gula Gorontalo & 0,42 \\
Gula Ratahan & 0,50 \\
Gula Motoling & 6,15 \\
\hline
\end{tabular}

\subsection{Pengukuran dengan Menggunakan Metode HPLC}

Tabel 3 menunjukkan waktu retensi dari asamasam standar yang di gunakan dalam penelitian ini. Pada gambar kromatogram di atas menunjukkan waktu retensi terkecil adalah asam malat, diikuti asam laktat, asetat, sitrat, piroglutamat, dan fumarat. Salah satu penyebab asam malat teridentifikasi pada menit ke 5,710 lebih cepat dari asam-asam standar lainnya, dikarenakan asam malat memiliki berat molekul yang lebih besar. Untuk asam askorbat tidak dicantumkan pada gambar dua dikarenakan asam askorbat merupakan asam terakhir yang diuji. Untuk waktu retensi asam askorbat yaitu 6,640.

Tabel 3 - Asam-asam Standar

\begin{tabular}{|l|l|}
\hline Asam-asam Standar & Waktu Retensi \\
\hline Malat & 5.710 \\
\hline Laktat & 7.312 \\
\hline Asetat & 8.048 \\
\hline Sitrat & 8.474 \\
\hline Piroglutamat & 9.635 \\
\hline Fumarat & 10.094 \\
\hline
\end{tabular}

Hasil penelitian menunjukkan beberapa kandungan asam-asam organik pada gula aren (gula merah) dan juga konsentrasi asam-asam organik tersebut dapat diidentifikasi dengan menggunakan HPLC dengan panjang gelombang $210 \mathrm{~nm}$, dapat dilihat pada beberapa Gambar 1 - 4.

Hasil penelitian dari beberapa gambar di atas dapat di lihat pada Tabel 4.

Tabel 4 menunjukkan bahwa dari keempat sampel gula aren, sampel dari Ratahan dan Kota Kotamobagu teridentifikasi mengandung asam asetat, piroglutamat, laktat, malat dan juga asam askorbat. Sedangkan sampel gula aren Gorontalo dan Motoling tidak mengandung. Tidak adanya asam asetat pada kedua sampel tersebut diduga 
disebabkan oleh menguapnya asam asetat sehingga tidak terbaca pada HPLC. Adanya asam-asam organik pada sampel gula aren menunjukkan bahwa gula tersebut mudah mengalami Kerusakan. Kerusakan dari gula merah disebabkan dari faktor bahan dasar untuk membuat gula merah yaitu nira. Karena menurut Marsigit (2005), pada proses fermentasi nira, kandungan brix akan menurun dengan cepat, sementara kandungan asam-asam seperti asam laktat dan tartarat cenderung akan meningkat.

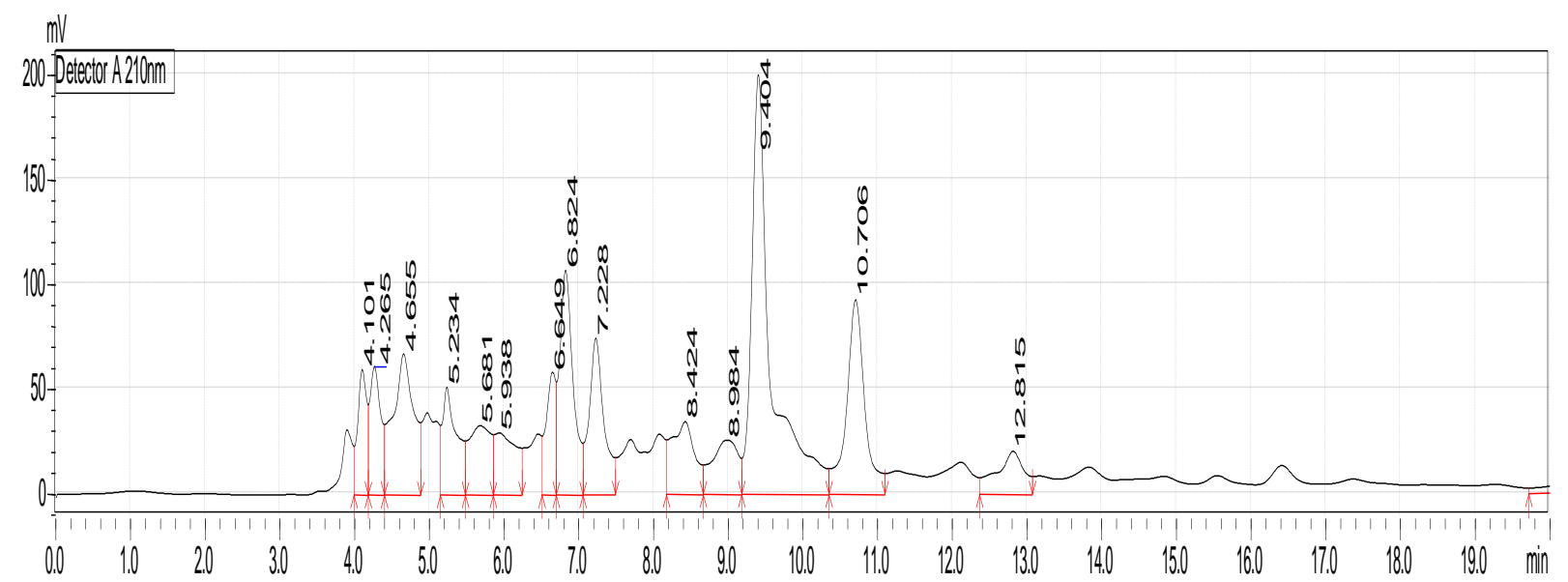

Gambar 1 - Kromatogram HPLC Sampel Gula Gorontalo

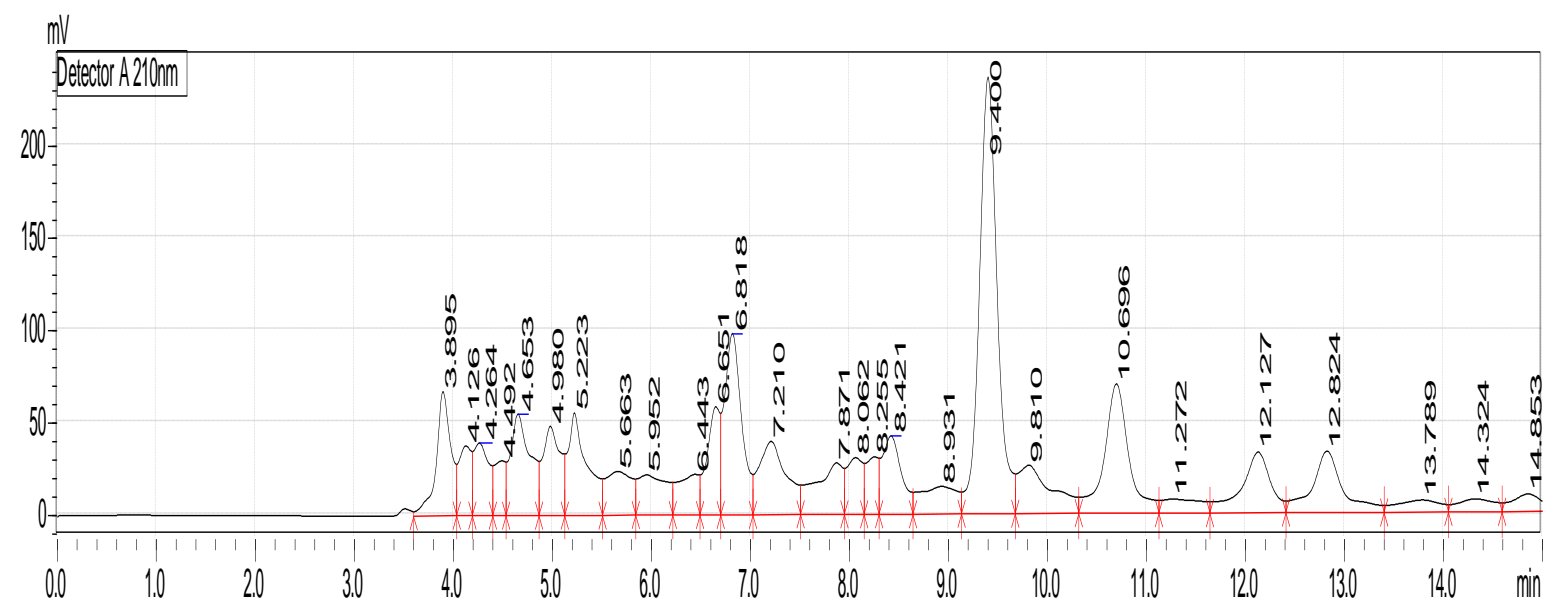

Gambar 2 - Kromatogram HPLC Sampel Gula Ratahan

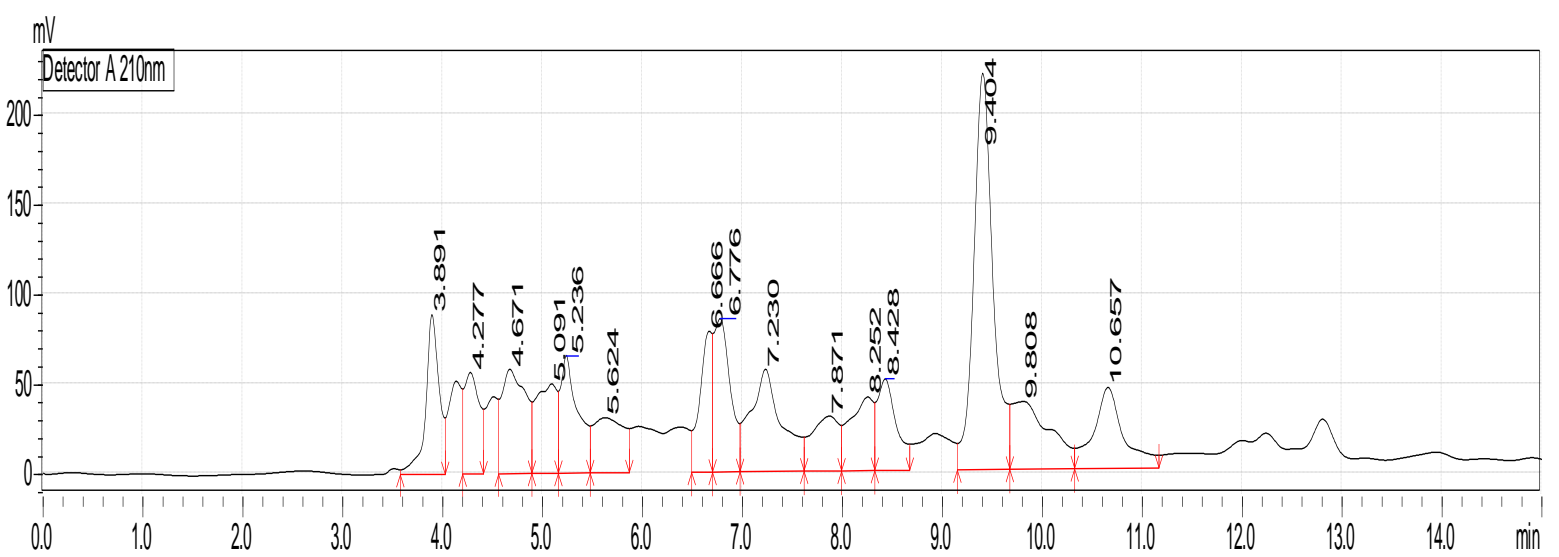

Gambar 3 - Kromatogram HPLC Sampel Gula 


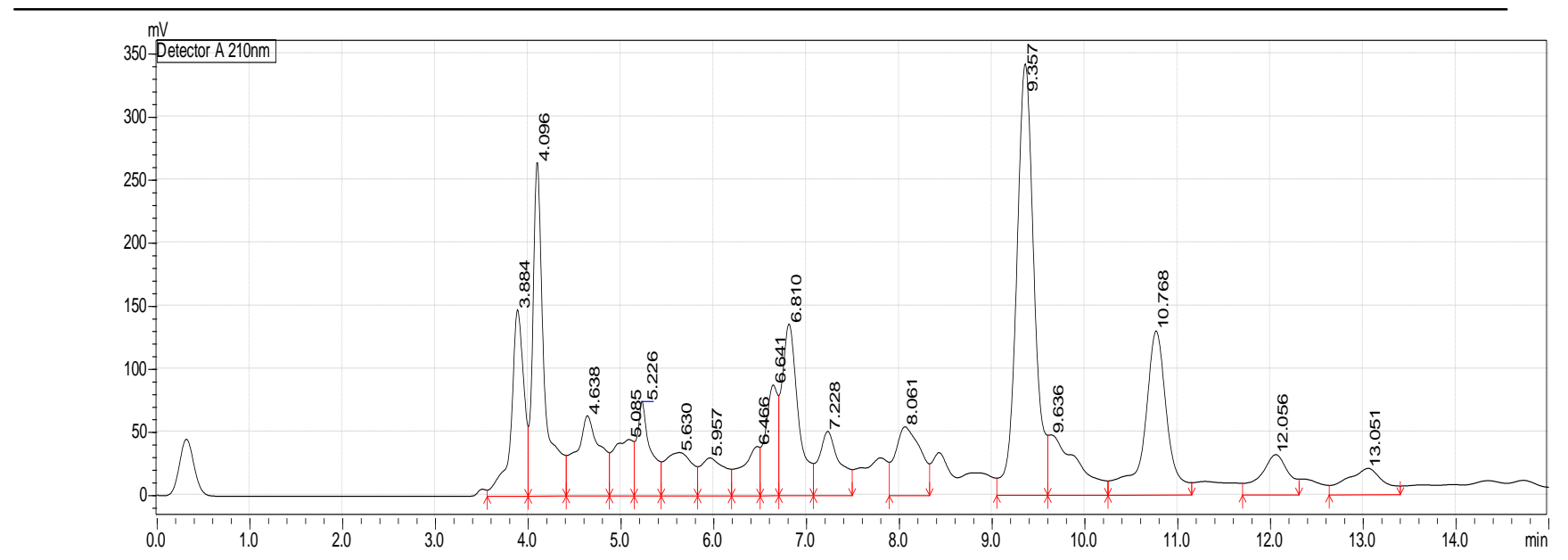

Gambar 4 - Kromatogram HPLC Sampel Gula Motoling

Adapun konsentrasi dari asam-asam standar dari masing-masing sampel dapat dilihat di Tabel 5.

Jenis asam organik yang terkandung dalam keempat sampel gula aren memiliki konsentrasi yang bervariasi dimulai dari yang terendah yaitu asam piroglutamat dengan konsentrasi dari setiap sampel sangatlah rendah sementara untuk konsentrasi rata- rata yang paling tinggi yaitu asam laktat, dikarenakan absortifitas molar dari asam piroglutamat lebih sensitif terhadap UV sehingga saat pembacaan pada UV asam piroglutamat dengan menggunakan konsentrasi yang rendah terbaca dengan puncak yang cukup tinggi ketimbang asam-asam organik yang lain pada kromatogram.

Tabel 4 - Waktu retensi untuk setiap sampel dan juga asam-asam standar menggunakan metode HPLC

\begin{tabular}{|c|c|c|c|c|c|}
\hline \multirow{2}{*}{ Sampel gula } & \multicolumn{5}{|c|}{ Waktu Retensi } \\
\cline { 2 - 6 } & Asetat & Piroglutamat & Laktat & Malat & Askorbat \\
\hline Gorontalo & - & 9,404 & 7,228 & 5,681 & 6,649 \\
\hline Ratahan & 7,871 & 9,400 & 7,210 & 5,663 & 6,651 \\
\hline $\begin{array}{c}\text { Kota } \\
\text { Kotamobagu }\end{array}$ & 8,061 & 9,636 & 7,228 & 5,630 & 6,641 \\
\hline Motoling & - & 9,404 & 7,230 & 5,624 & 6,666 \\
\hline
\end{tabular}

Tabel 5 - Konsentrasi rata- rata asam-asam standar dari setiap sampel (g/100g)

\begin{tabular}{|l|l|l|l|l|}
\hline \multirow{2}{*}{ Asam-Asam } & \multicolumn{4}{|l|}{ Konsentrasi Sampel $(\%)$} \\
\cline { 2 - 5 } & Ratahan & Kota Kotamobagu & Motoling & Gorontalo \\
\hline Malat & 0,96 & 0,88 & 1,16 & 0,95 \\
\hline Laktat & 3,95 & 3,07 & 3,73 & 3,93 \\
\hline Piroglutamat & 0,58 & 0,09 & 0,58 & 0,58 \\
\hline Asetat & 0,92 & 3,01 & 0 & 0 \\
\hline Askorbat & 0,70 & 0,54 & 0,64 & 0,85 \\
\hline Jumlah & 7,12 & 7,59 & 6,12 & 6,31 \\
\hline
\end{tabular}

Untuk sampel gula gorontalo nilai konsentrasi rata-rata asam piroglutamat yaitu untuk gula Ratahan 0,58\%, Kota Kotamobagu 0,09\%, Gorontalo 0,58\% dan Motoling $0,58 \%$. Sementara untuk nilai konsentrasi rata-rata asam laktat pada sampel gula Gorontalo 3,93\%, gula Ratahan 3,95\%, gula Kota Kotamobagu 3,07\% dan Motoling 3,73\%. Sehingga sampel gula kotamobagu memiliki jumlah asam organik yang lebih tinggi dibandingkan dengan sampel gula lainnya, hal ini dikarenakan salah satu faktor utamanya yaitu sampel gula Kota Kotamobagu teridentifikasi memiliki kelima asam standar yang digunakan dibandingkan dengan sampel gula Motoling dan sampel gula Gorontalo. Untuk sampel gula Ratahan teridentifikasi memiliki kelima asam standar yang digunakan, akan tetapi konsentrasinya lebih rendah dari sampel gula Kota Kotamobagu.

Hasil perhitungan konsentrasi menggunakan metode titrasi dan menggunakan metode HPLC tidak sama. Hal ini mungkin disebabkan oleh adanya interprensi warna dari gula merah sehingga sukar menentukan titik akir dari pada titrasi. Untuk keasaman $(\mathrm{pH})$ tidak dapat dijadikan patokan untuk 
menentukan keasaman pada gula, karena gula masih menggandung bahan-bahan lain yang bersifat buffer.

4. Kesimpulan

Nilai pH dari hasil penelitian berkisar antara 5,17 $-5,88$

Nilai konsentrasi total asam berada dalam kisaran 0,39 - 6,15 g/100g

Dari hasil identifikasi sampel gula menggandung asam-asam organik berupa asam piroglutamat, malat, laktat, askorbat dan asetat. Sedangkan sampel gula Motoling dan sampel gula Gorontalo hanya mengandung 4 jenis asam yaitu piroglutamat, malat, laktat dan askorbat.

Hasil perhitungan konsentrasi dari kelima asam standar diperoleh konsentrasi tertinggi yaitu asam laktat kisaran 3,07-3,95 g/100g dan yang terendah yaitu asam piroglutamat kisaran 0,09-0,58 g/100g dengan menggunakan metode HPLC.

Tidak adanya kolerasi antara $\mathrm{pH}$, total asam dan konsentrasi asam-asam organik yang menggunakan HPLC.

\section{Daftar Pustaka}

Ardianingsih, R. 2009. Penggunaan High Performance Liquid Chromatography (HPLC) dalam Proses Analisa Deteksi Ion. Berita Dirgantara. 10: 101104.

Baharuddin., M. Muin., dan H. Bandaso. 2007. Pemanfaatan Nira Aren (Arenga pinnata Merr) Sebagai Bahan Pembuatan Gula Putih Kristal. Jurnal Perennial. 3: 40-43.

Bizri, M. J., and A. L. Wahem. 1994. Citric Acid and Antimicrobials Affect Microbiological Stability and Quality of Tomato Juice. Jurnal of Food Science. 59: 130-134.

Day., dan Underwood. 1999. Analisis Kimia Kuantitatif. Erlangga, Jakarta.

Effendi, D. S. 2009. Aren, Sumber Energi Alternatif. Warta Penelitian dan Pengembangan Pertanian. 31: 1-3.

lijima, S., Y. Sato., M. Bounoshita., T. Miyaji., D. J. Tongnarelli., dan M. Saito. 2013. Optimization of an Online Post-Column Derivatization System for Ultra HighPerformance Liquid Chromatography (UHPLC) and Its Applications to Analysis of Biogenic Amines. Journal Analytical Science. 29: 539-545.

Kalengkongan, C., J. Pontoh., dan F. Fatimah. 2013. Hubungan Antara Beberapa Kriteria Kualitas dengan Warna Gula Aren (Arenga pinnata Merr.). Jurnal IImiah Sains. 13: 86-92.

Limo, S. R., J. Pontoh., dan A. D. Wuntu. 2015. Analisis Beberapa Asam Organik Dalam Nira Aren Menggunakan Hplc Fasa Terbalik Kolom Ymc Triart C18. (Siap diterbitkan)

Pelealu, K., J. Pontoh., dan E. Suryanto. 2011. Pengaruh Pemanasan Terhadap Aktivitas Antioksidan dalam Pembuatan Gula Aren. Chemistry Progress. 4: 60-65.

Pontoh, J. 2013. Penentuan kandungan sukrosa pada gula aren dengan metode enzimatik. Journal Chemistry Progress. 6: 26-33.

Pontoh, J., G. Indriani., dan F. Fatimah. 2011. Analisa Kandungan Protein dalam Nira Aren. Chemistry Progress. 4: 75-79.

Zeppa, G., L. Conterno., and V. Gerbi. 2001. Determination of Organic Acids, Sugars, Diacetyl, and Acetoin in Cheese by HighPerformance Liquid Chromatography. Journal Agric Food Chemis. 49: 2722-2726. 